\title{
THE DiLEMMAS OF TAX COORDINATION IN THE ENLARGED EUROPEAN UNION
}

\author{
JENS BRØCHNER \\ JESPER JENSEN \\ PATRIK SVENSSON \\ PETER BIRCH SøRENSEN
}

\section{CESIFO WORKING PAPER NO. 1859}

CATEGORY 1: Public FinANCE

NOVEMBER 2006

An electronic version of the paper may be downloaded

- from the SSRN website:

- from the RePEc website:

www.SSRN.com

from the CESifo website:

Www.RePEc.org

www.CESifo-group.de 


\title{
THE DiLEMMAS OF TAX COORDINATION IN THE ENLARGED EUROPEAN UNION
}

\begin{abstract}
This study evaluates the economic effects of corporate tax coordination in the enlarged European Union using a computable general equilibrium model and a comprehensive set of scenarios for both a common corporate EU tax base and for full harmonisation of tax bases and tax rates. Our main findings are as follows: (i) Corporate tax coordination can yield modest aggregate welfare gains, but the details of the coordination policies determine outcomes and economic gains cannot be taken for granted. (ii) All scenarios for coordination leave some EU Member States as winners and others as losers. An agreement on tax coordination is therefore likely to require elaborate compensation mechanisms. (iii) The large and diverse country effects suggest that Enhanced Cooperation for a subset of the Member States may be the most likely route towards tax coordination. Coordination among a subset of relatively homogenous Member States will lead to less radical policy changes, but also to smaller gains. (iv) Identifying winners and losers from coordination for the purpose of a compensation mechanism may be problematic, since countries experiencing gains in GDP and welfare tend to lose tax revenues, and vice versa.
\end{abstract}

JEL Code: H87, H77.

Jens Brøchner

The Danish Ministry of Finance

Copenhagen

Denmark

Patrik Svensson

Quartz Strategy Consultants

\author{
Jesper Jensen \\ TECA TRAINING ApS \\ Copenhagen \\ Denmark
}

Peter Birch Sørensen

Department of Economics

University of Copenhagen

Studiestraede 6

1455 Copenhagen $K$

Denmark

peter.birch.sorensen@econ.ku.dk

October 2006, second draft 


\section{The Dilemmas of Tax Coordination in the Enlarged European Union}

Jens Brøchner, Jesper Jensen, Patrik Svensson and Peter Birch Sørensen ${ }^{1}$

\section{Introduction}

A basic goal of the European Union is to create an integrated European economy where the free flows of goods, services and factors of production are not distorted by national economic policies. Ever since the inception of the EU, it has been recognized that differences in national tax systems may cause a misallocation of resources within the Union. To eliminate such tax-induced distortions, the European Commission, as well as several independent experts, have repeatedly called for various forms of tax coordination within the EU.

In particular, there have been many proposals for coordination of the corporate tax systems of the Member States. Already in 1962, the Neumark Committee proposed a common imputation system with a split corporate tax rate for retained and distributed profits. By contrast, the Tempel report of 1970 suggested a common classical system of corporate taxation. In 1975, the European Commission proposed a directive providing for corporate tax rates to fall within a range of 45-55 percent, a partial imputation system and a common 25 percent withholding tax on dividends. In 1988 the Commission proceeded with draft proposals for a harmonised corporate tax base, and in 1992 an expert committee chaired by Onno Ruding suggested minimum and maximum standards for corporate tax rates and tax bases in

\footnotetext{
${ }^{1}$ This paper is an extension of a study carried out for the European Commission (see Copenhagen Economics, 2004). The original study was completed while Jesper Jensen and Patrik Svensson worked for Copenhagen Economics. The paper reflects the views of the authors. The European Commission is not liable for any use that may be made of the information contained in the paper. Thanks are due to the European Commission's steering group for the original study, Matthias Mors and Christian Keuschnigg. We also appreciate comments from Andrew Haughwout and other participants in the IFIR-CESifo conference on "New Directions in Fiscal Federalism” in Lexington, Kentucky, September 14-16, 2006. All remaining errors are the responsibility of the authors.
} 
the EU. More recently, the Commission put forward alternative proposals for the introduction of a common consolidated tax base for European multinationals (European Commission, 2001a).

However, although the Commission has had some success in alleviating international double taxation in the sphere of corporate taxation (mainly via the Parent-Subsidiary directive and the Interest and Royalties directive), none of the more ambitious proposals for harmonisation or coordination mentioned above have been adopted by the EU Member States. ${ }^{2}$ By identifying some fundamental dilemmas for EU tax coordination, the present study may help to explain why progress on coordination has been so slow. Thus we show that while the EU-wide economic gains from tax harmonisation arise from differences in the national tax systems, these differences also imply that some Member States are bound to lose from harmonisation. Given the current unanimity rule for tax policy decisions in the EU, harmonisation is therefore unlikely to occur unless the winners can somehow compensate the losers. But this raises another dilemma: According to our analysis the countries experiencing gains in GDP and welfare will also tend to lose tax revenue as a result of tax harmonisation, whereas Member States suffering a loss of GDP and welfare will actually tend to gain additional tax revenue. Hence it seems unlikely that the governments of the former countries will be willing and able to transfer resources to the governments of the latter countries.

Our analysis is based on an elaborate computable general equilibrium model comprising all the 25 current Member States of the EU plus ten additional countries representing the rest of the world. To our knowledge, the present paper is the first study to undertake a quantitative analysis of tax coordination in the enlarged European Union, accounting for economic interactions between the EU and the rest of the world, and allowing for a rich variety of assets and alternative tax instruments. Thus the present study extends previous quantitative studies of tax coordination in the EU based on more aggregated and stylized models, such as the papers by

\footnotetext{
2 For recent status reports on company tax coordination in Europe, see European Commission (2003) and Nicodème (2006).
} 
Mendoza and Tesar (1998, 2005), Sørensen (2000, 2001a, 2004a, 2004c) and Bettendorf et al. (2006). ${ }^{3}$

The next main section describes our simulation model, and section 3 lays out the various scenarios for tax coordination to be considered. Section 4 presents and discusses the simulated effects of alternative policy scenarios. Our main conclusions are summarized in section 5 which also raises some caveats. The appendix provides a more detailed documentation of our results.

\section{The model}

Our evaluation of policy scenarios for tax coordination is based on CETAX, a simulation model building on the OECDTAX model developed by Peter Birch Sørensen (Sørensen, 2001b; 2004b). The OECDTAX model was constructed specifically for the purpose of studying international coordination of capital income taxation. It has already been applied to a range of policy issues such as corporate tax harmonization in the EU, corporate tax reform in Germany and shifts between corporate taxes and taxes on labour (Sørensen, 2002; 2004a; 2004b).

The CETAX model extends the OECDTAX model in two ways. First, while the original OECDTAX model incorporated 24 OECD countries, including the 15 'old' EU Member States, the CETAX model includes all new Member States, covering the whole EU25 plus nine other OECD countries and a tax haven jurisdiction. ${ }^{4}$ Second, the model database has been extended to account both for the geographical extension with the new Member States and for new model features, including the tax systems of the new Member States and a more detailed modelling of transaction costs associated with foreign portfolio investment. ${ }^{5}$

3 The CORTAX model developed by Bettendorf et al. (2006) is a simplified version of the model presented here. The CORTAX model only includes 17 EU countries and no countries representing the rest of the world. Moreover, unlike our model, the CORTAX model assumes that the EU cannot affect the international returns on stocks and bonds, and it abstracts from the housing market, financial institutions, labour market imperfections and tax havens.

4 The other OECD countries included in the model are Australia, Canada, Iceland, Japan, New Zealand, Norway, Switzerland, Turkey and the United States.

5 These transactions costs are now calibrated on a bilateral country-by country basis in order to generate a more realistic pattern of cross-country investment in debt instruments. 


\subsection{General model features ${ }^{6}$}

The CETAX model is a CGE model describing the international spill-over effects of national tax policies via the world capital market. Each country in the model includes a household sector, a business sector and a government, and all countries are linked together via international capital markets and trade in goods and services. The model features private portfolio composition, endogenous corporate financial policies, incorporation of a housing market, a distinction between foreign direct investment and foreign portfolio investment, explicit modelling of the financial sector and a detailed description of tax systems. The model can be used both to analyse the effects of unilateral changes in tax policies and various forms of international tax coordination.

The CETAX model is static, describing a stationary equilibrium. It includes 35 countries representing the European Union and the Rest of the World (ROW). One country in the ROW is a tax haven that facilitates tax evasion. Each country produces the same homogeneous good, which is traded in an integrated international goods market. Labour is immobile across countries, whereas capital is imperfectly mobile. The supply of capital to an individual country is thus an increasing function of the rate of return offered in that country. By parametrically varying the elasticity of substitution between assets invested in different countries, one can vary the degree of capital mobility and approximate a situation of perfect mobility. The model is specifically designed to allow for higher capital mobility within the EU than between the EU and the ROW.

\subsection{Households}

Households in each country must choose between immediate and postponed consumption, and the utility-maximising consumer increases his total saving as the after-tax real rate of return increases. Hence the total supply of capital is endogenous.

\footnotetext{
6 This section outlines the main features of our model. An exhaustive analytical description of the model can be found in the OECDTAX model documentation (Sørensen, 2001b).
} 
Having optimized his total saving, the consumer divides his funds between investment in housing equity and financial saving. In the next step, he allocates financial saving between institutional saving and 'household saving'. Household saving includes direct household purchases of stocks and debt instruments, including bank deposits. Institutional saving incorporates financial saving channelled through pension funds and life insurance companies, plus pension savings via the banking and corporate sectors.

In a subsequent step, household financial saving is allocated between stocks and interest-bearing assets, denoted 'bonds' for convenience. Each of these two aggregates must then be allocated between domestic and foreign assets which in turn must be allocated between assets issued in the EU region and assets issued in the ROW. In the final stage, the portfolio is split into assets issued in the individual countries. The institutional savings are allocated across similar asset types in a similar manner.

In addition to supplying capital (savings) to the domestic and international capital markets, households supply labour to domestic and international firms operating in the domestic economy. Wages and working hours are set by trade unions whose market power generates involuntary unemployment. By incorporating labour market imperfections, the model thus addresses the concern of policy makers that a possible shift of the tax burden towards labour may cause more (involuntary) unemployment.

\subsection{Firms}

Businesses are modelled as either purely domestic firms with no international operations or as multinational parent companies with fully owned subsidiaries in each of the other countries of the world. Each country is endowed with a fixed stock of intangible assets representing e.g. human capital and management know-how. A fraction of these assets is held by multinationals, the rest by domestic firms. Domestic firms issue debt to domestic and foreign investors. The equity shares in these firms are not traded internationally, but are held only by domestic households.

By contrast, multinational corporations issue shares as well as debt instruments to foreign as well as domestic household and institutional investors. The 
multinational parent companies inject equity into foreign subsidiaries, representing foreign direct investment, and provide their subsidiaries with intermediate inputs. Subsidiaries also borrow in the host country capital market. Factor demands and financial policies are chosen to maximize global after-tax profits. Multinationals have the possibility to engage in transfer pricing to shift taxable profits between parent and subsidiaries. In setting their transfer prices, multinationals trade off the organizational cost of distorted input prices against the tax advantage of shifting profits into low-tax jurisdictions. ${ }^{7}$

\subsection{The public sector}

The government of each country provides infrastructure, other public goods and income transfers. Public expenditures are financed through a long list of direct taxes on capital and labour as well as via indirect taxes on goods and services.

Real world tax codes are complex, distinguishing between e.g. foreign direct investment and foreign portfolio investment, between household investors and institutional investors, between housing investment and financial investment, between current income and capital gains, and between debt and equity. Moreover, while some types of foreign investment are taxed in the country of source, other income types are taxed in the investor's country of residence.

The model provides a detailed representation of capital taxation, incorporating all of these distinctions. Specifically, the direct taxes in the model include taxes on corporate profits, interest income, dividends and capital gains, as well as taxes on labour income and on the imputed rent from owner-occupied housing (where such a tax exists). The model also includes withholding taxes on interest and dividends and a number of policy variables indicating the extent to which governments engage in international exchange of information to enforce residence-based income taxation. Finally, the model accounts for the various

\footnotetext{
7 Being static, the model does not illustrate the dynamics of capital stock adjustment and does not include adjustment costs. In this sense, the model describes a long-run equilibrium. On the other hand the model assumes that national endowments of intangible assets are fixed. In the very long run such assets may become mobile internationally, so the time horizon of the model may best be thought of as a medium to long run of about 10 years.
} 
methods used to alleviate the domestic and international double taxation of corporate income.

\subsection{Calibration}

A general equilibrium in CETAX is established when households and trade unions maximise their utilities, firms maximise profits, and all national markets for bonds and stocks are clearing.

The simultaneity of the model means that most endogenous variables depend on all model parameters, but some parameters can be assigned the task of generating realistic values of certain endogenous variables (see Sørensen, 2001b). When calibrating the model, parameters for initial endowments of e.g. wealth and intangible assets have thus been chosen so as to generate realistic relative levels of GDP and national income. Labour market parameters have been set to replicate current unemployment rates, and financial sector fees have been set to produce plausible values of the financial sector income ratio in individual countries. In this way, calibration and the choice of parameter values have been performed much in the same way as in previous applications of the OECDTAX model (e.g. Sørensen, 2002; 2004a; 2004b). The primary data source for the calibration has been OECD national accounts and OECD revenue data, supplemented by various national sources for some of the new EU Member States.

The most contentious calibration issue in the context of this study is the calibration of the parameter defining the broadness of the tax base, i.e. the rate of depreciation for tax purposes. This parameter is calibrated to replicate the empirically observed ratio of corporate tax revenue to GDP, so its value depends on recorded corporate tax revenue. This figure tends to vary significantly over time and even across different data sources (e.g. OECD and Eurostat). Individual country results may consequently vary with the data to which the model is calibrated. The aggregate effects are, however, less affected by this issue.

The corporate tax revenue data and corporate tax rates used for the calibration of the rate of depreciation for tax purposes are provided in Table 1. Because the most recent revenue statistics for corporate income taxes cover the year 
2001, corporate tax rates for 2001 have been used to calibrate the rate of depreciation for tax purposes, in order to maintain consistency in the calibration. ${ }^{8}$

When we evaluate the effects of EU tax coordination, we start from a baseline equilibrium reflecting the corporate tax rates in force in 2004, which are also reported in Table 1. Primary sources for tax data are Eurostat (2003), Eurostat (2004), Sørensen (2004a), Martinez-Serrano and Patterson (2003), the Danish Ministry of Taxation (2004) and ZEW (2003).

\footnotetext{
${ }^{8}$ An implication of using 2001 as the base year is that German corporate tax revenues are somewhat lower than normal due to once-off effects in that year. As a result, the calibrated rate of depreciation for tax purposes becomes artificially high for Germany in the model baseline. With Germany being an outlier in terms of its relative level of corporate tax revenues already at more normal levels, however, the calibration is unlikely to affect any policy conclusions.
} 
Table 1. Tax data used for calibrating the model

\begin{tabular}{|c|c|c|c|}
\hline Member State & $\begin{array}{l}\text { Taxes on corporate } \\
\text { income (\% of } \\
\text { GDP) }\end{array}$ & $\begin{array}{l}\text { Corporate tax rate } \\
\text { (2001) }\end{array}$ & $\begin{array}{l}\text { Corporate tax rate } \\
\text { (2004) }\end{array}$ \\
\hline Austria & 3.1 & $34 \%$ & $34 \%$ \\
\hline Belgium & 3.6 & $40 \%$ & $34 \%$ \\
\hline Denmark & 3.1 & $30 \%$ & $30 \%$ \\
\hline Finland & 4.9 & $29 \%$ & $29 \%$ \\
\hline France & 3.4 & $35 \%$ & $35 \%$ \\
\hline Germany & 0.6 & $39 \%$ & $38 \%$ \\
\hline Greece & 3.4 & $37 \%$ & $35 \%$ \\
\hline Ireland & 3.6 & $20 \%$ & $12,5 \%$ \\
\hline Italy & 3.6 & $36 \%$ & $33 \%$ \\
\hline Luxembourg & 7.5 & $37 \%$ & $30 \%$ \\
\hline Netherlands & 4.1 & $35 \%$ & $34,5 \%$ \\
\hline Portugal & 3.6 & $35 \%$ & $27,5 \%$ \\
\hline Spain & 2.8 & $35 \%$ & $35 \%$ \\
\hline Sweden & 2.9 & $28 \%$ & $28 \%$ \\
\hline United Kingdom & 3.5 & $30 \%$ & $30 \%$ \\
\hline Cyprus & 2.4 & $25 \%$ & $15 \%$ \\
\hline Czech Rep. & 4.2 & $31 \%$ & $28 \%$ \\
\hline Estonia & 0.7 & $26 \%$ & $26 \%$ \\
\hline Hungary & 2.4 & $18 \%$ & $16 \%$ \\
\hline Latvia & 2.0 & $22 \%$ & $15 \%$ \\
\hline Lithuania & 2.0 & $15 \%$ & $15 \%$ \\
\hline Malta & 2.4 & $35 \%$ & $35 \%$ \\
\hline Poland & 2.0 & $28 \%$ & $19 \%$ \\
\hline Slovak Rep. & 2.2 & $25 \%$ & $19 \%$ \\
\hline Slovenia & 1.4 & $25 \%$ & $25 \%$ \\
\hline
\end{tabular}

Note: The corporate tax rate is applied equally to retained and distributed profits, except for Estonia, where retained profits are tax exempt.

Source: Eurostat (2003, 2004), Martinez-Serrano \& Patterson (2003), OECD (2003), KPMG (2001, 2004), Danish Ministry of Taxation (2004), ZEW (2003) and own calculations based on national accounts.

The source of all model elasticities is Sørensen (2002, 2004b). Table 2 reports selected elasticities in the model. The substitution elasticities between different types of assets and the international transaction cost parameters have been chosen to generate realistic patterns of portfolio composition. The elasticities generate an equilibrium where interest rate differentials are relatively small across 
the OECD, as empirically observed, but the calibration of investor preferences also reproduces the observed home bias in investor portfolios.

Table 2. Selected model elasticities

\begin{tabular}{lr}
\hline Parameter & Value \\
\hline Elasticity of saving with respect to the after-tax rate of return & 0.2 \\
Elasticity of labour supply with respect to the after-tax wage rate & 0.2 \\
Elasticity of substitution between housing assets and financial assets & 1 \\
Elasticity of substitution between household saving and institutional saving & 1 \\
Elasticity of substitution between stocks and bonds & 4 \\
Elasticity of substitution between foreign and domestic stocks held by households & 3.5 \\
Elasticity of substitution between foreign and domestic bonds held by households & 4 \\
\hline
\end{tabular}

Source: Sørensen (2002, 2004b).

\section{Policy scenarios}

Tax coordination encompasses a wide range of possible tax instruments and coordination policies. The following sections describe the three scenarios of harmonisation of tax rates and tax bases considered in this study. A baseline provides a benchmark for the scenario analysis. The baseline equilibrium includes all current tax policies in the field of direct taxation in the EU25.

\subsection{Full harmonisation}

Our first policy scenario is highly ambitious, envisaging full harmonisation of corporate tax bases and tax rates in the EU25 with the purpose of eliminating all corporate tax distortions to the cross-country pattern of investment. A harmonised tax rate implies that all Member States apply the same statutory rate which is imposed equally on retained and distributed profits. A harmonised tax base means that all Member States adopt the same rules for calculating the corporate tax bases in their respective territories. The broadness of the tax base in the model is determined by the rate of capital depreciation and the proportion of interest payments that may be deducted against taxable corporate income. The scenario with full harmonisation creates a harmonised tax base across the EU25 by assuming that the capital allowance rate and the proportion of deductible interest payments will be identical for all Member States. All parameters other than the statutory corporate tax rate, the 
capital allowance rate and the deductible fraction of interest payments are assumed to be unchanged compared to the baseline scenario. ${ }^{9}$

The harmonised tax rates and tax bases are calculated as an average across the EU25. In one version of the scenario an unweighted average applies, and in a second version a GDP-weighted average is considered.

\subsection{Tax base harmonisation}

As a compromise between full tax harmonisation and unfettered tax competition, some participants in the European policy debate have proposed to harmonise the corporate tax base while leaving Member States free to choose their own preferred statutory corporate tax rate. With tax base harmonisation European multinationals would save on compliance costs, and national differentials in statutory tax rates would more accurately reflect differences in effective tax rates, increasing the transparency of corporate tax systems. At the same time Member States could still compete over statutory tax rates, thus preserving an important element of national sovereignty in tax policy.

Against this background our second scenario assumes full harmonisation of corporate tax bases across the EU25. This policy package is identical to the full harmonisation scenario with respect to harmonisation of tax bases, but leaves statutory tax rates at their current levels. Again, the tax bases are calculated as two different (unweighted and GDP-weighted) averages of the current tax bases.

\subsection{Enhanced Cooperation}

Enhanced Cooperation between a subset of the Member States is more likely than agreement amongst all 25 EU Member States. The legal basis for Enhanced Cooperation is the Treaty of Nice, which mandates that at least 8 Member States

\footnotetext{
${ }^{9}$ In particular, all scenarios assume separate accounting, as it is currently the practice, and ignore the issue of consolidated accounting, where multinational firms would have a single set of accounts for their EU-wide operations. Tax revenues would then be distributed among Member States according to an apportionment mechanism. See Sørensen (2004a) for a discussion of such a regime.
} 
must decide to move forward. The perhaps most interesting subset consists of the 12 Member States that have adopted the Euro as their common currency. ${ }^{10}$

In our scenario with Enhanced Cooperation, we therefore assume that tax bases as well as tax rates are harmonised at the unweighted or weighted average levels prevailing across the Euro countries only, leaving tax rates and tax bases in the other EU Member States at their current levels.

\subsection{The method of finance}

Tax coordination will generally affect the total public revenue collected by Member States. In order to isolate the 'pure' effects of tax coordination, most of our analysis will assume that long-run government budget balance is maintained through adjustment of (lump-sum) income transfers to households. However, to illustrate the importance of the marginal source of public finance, we will also study the effects of full harmonisation when tax rates on labour income are adjusted to balance the public budget.

\section{Effects of tax coordination on economic activity, public revenue and consumer welfare}

Two factors explain the majority of the economic effects of corporate tax harmonisation. First, harmonisation of both tax rates and tax bases reduces crosscountry differences in effective tax rates, leading to a more efficient allocation of capital within the EU as corporate taxes no longer drive a wedge between the marginal productivity of capital in the different Member States. The aggregate EUwide gain from a more efficient capital allocation may be seen as the pure valueadded from tax coordination. Note that while such a gain will always arise under full harmonisation, it may not materialize under tax base harmonisation, because the latter scenario will not necessarily reduce cross-country differences in effective corporate tax rates.

\footnotetext{
${ }^{10}$ The 12 Member States are: Austria, Belgium, Finland, France, Germany, Greece, Ireland, Italy, Luxembourg, Netherlands, Portugal and Spain.
} 
Second, in all scenarios where the public budget is balanced through adjustment of public transfers, corporate tax harmonisation will increase the tax burden in some countries and reduce it in other countries. The policy changes required can be very significant. Individual country results are primarily influenced by the change in the overall tax burden. A higher tax burden leads to higher tax revenues but causes a loss in GDP due to increased distortions. Conversely, a lower tax burden generates a drop in tax revenue and a gain in GDP stemming from greater economic efficiency. The aggregate effect of changes to the total level of taxation often dominates the effect of a more efficient allocation of capital. Large shifts in total tax revenues will in many cases lead to large shifts in GDP. This means that economic gains from tax coordination cannot be taken for granted. Depending on the specific details of coordination policies and the set of cooperating countries, aggregate gains can be reversed into aggregate losses. The details of policy reform matter, as will be shown in the following sections.

\subsection{Aggregate effects of tax coordination}

Figures 1 and 2 summarize the EU-wide effects of tax coordination in the two cases of harmonisation at unweighted and weighted averages, respectively. EUwide harmonisation (both full and base harmonisation) leads to gains in both GDP and welfare. ${ }^{11}$ Harmonisation at unweighted averages leads to a significant drop in tax revenues. As explained above, the aggregate effect of changes to the total level of taxation can often dominate the effects of a more efficient allocation of capital.

\footnotetext{
${ }^{11}$ Because the labour supply and savings schedules in the CETAX model are derived from a quasi-linear utility function that eliminates income effects, our measure of consumer welfare corresponds to the equivalent as well as to the compensating variation.
} 
Figure 1. EU-wide impact of tax coordination (unweighted averages)

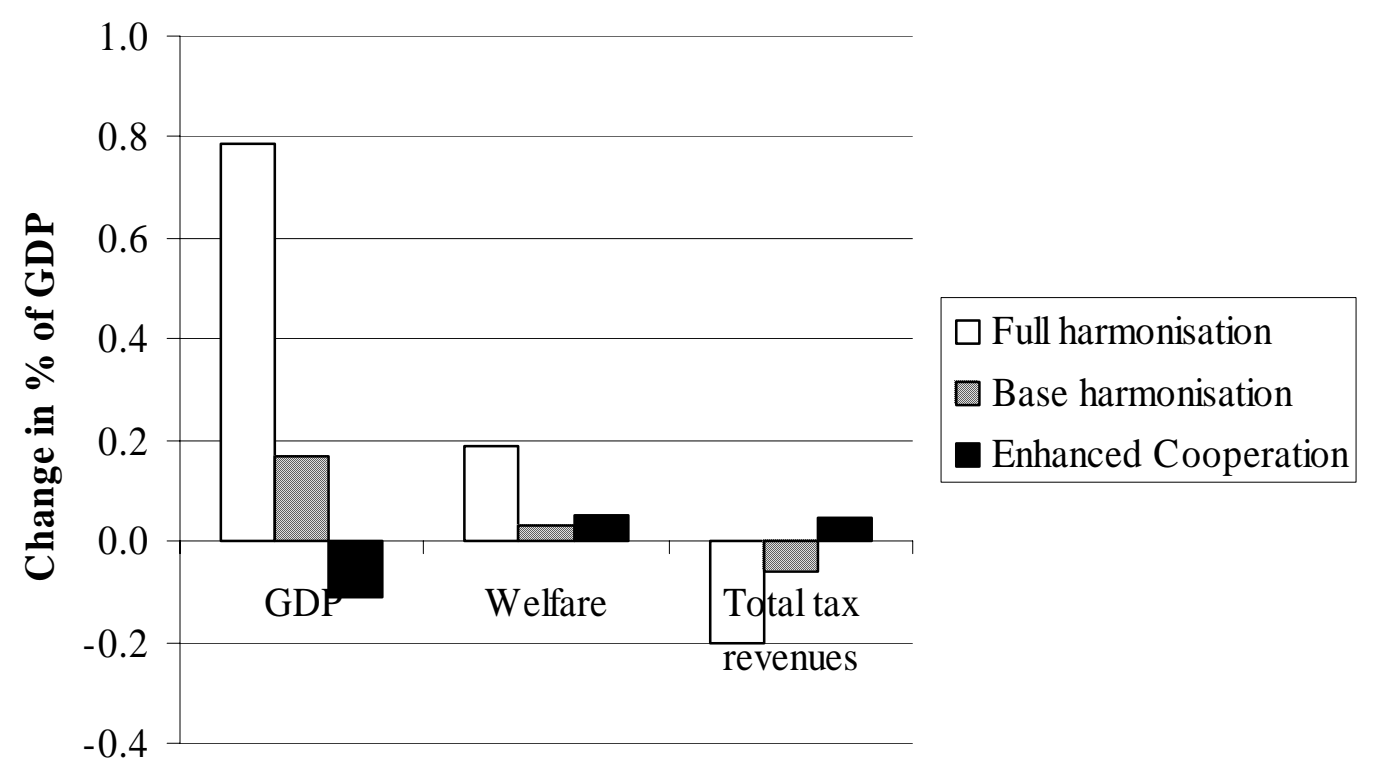

Figure 2. EU-wide impact of tax coordination (weighted averages)

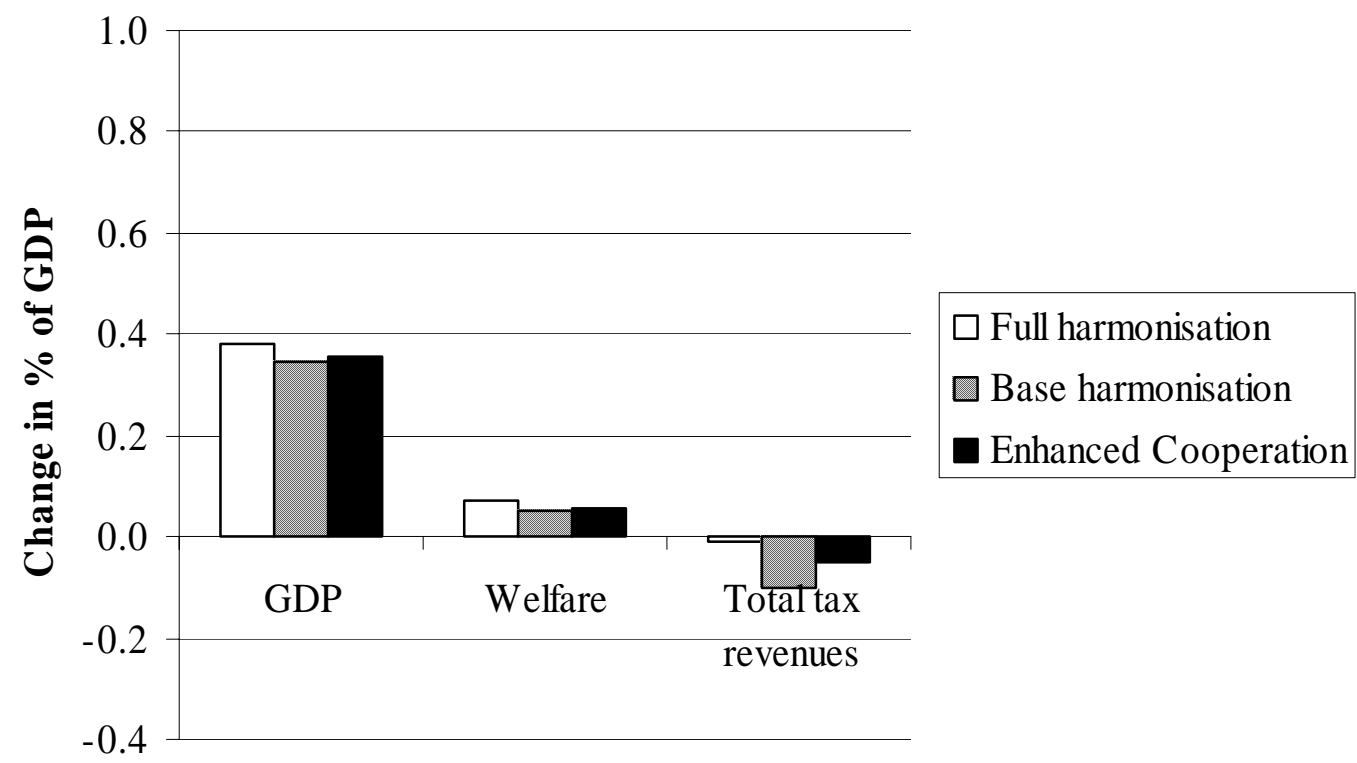

In the case of full harmonisation at the weighted average tax rate and base, GDP and welfare are seen to increase by almost $0.4 \%$ and $0.1 \%$, respectively, while aggregate tax revenue for the EU25 is virtually constant. The aggregate gains in both 
GDP and welfare are indicative of the positive effect of a more efficient capital allocation, and can be thought of as the pure benefit from tax coordination.

It may seem surprising that GDP and welfare move in opposite directions in the case of Enhanced Cooperation. However, the two variables need not move in parallel, since an increase in GDP requires an increase in factor inputs which is costly in terms of welfare, and since GDP and national income may be decoupled because changes in net capital flows generate changes in income from net foreign assets. For example, consider a country that allows strongly accelerated depreciation so that even investments with a very low pre-tax rate of return are profitable. If such a country is forced to reduce its capital allowance rate as a consequence of tax harmonisation, domestic investment and GDP will tend to fall, but national income and welfare may increase, since a larger fraction of national savings will be invested in the international capital market rather than being used to finance low-productive domestic investment.

The relatively modest magnitude of the welfare gains in Figures 1 and 2 is explained by the continued existence of other tax distortions to the cross-country pattern of saving and investment within the EU (see Sørensen, 2004a). Tax rules for household and institutional investors still differ across Member States. In particular,

the taxation of corporate source income at the shareholder level continues to differ across countries. Investors are furthermore home-biased in their decision making, which reduces the substitutability of assets. Moreover, a significant part of total capital stocks is invested outside the corporate sector, particularly in housing capital. Corporate tax harmonisation alone is therefore not enough to equalize the cost of capital across the EU.

\subsection{Effects of tax harmonisation on individual Member States}

Though the aggregate effects of tax coordination are quite modest at the EU level, individual country effects are large and divergent, as illustrated in Table 3, which considers the scenario with full harmonisation at unweighted averages. The table shows that individual countries will experience sizeable changes in economic activity and tax revenues. Two conclusions emerge. First, harmonisation of the corporate tax base implies very large changes to the rules determining taxable corporate income in some countries. In particular, Germany is an outlier in the EU15 
because of its narrow tax base. Second, for almost all countries, a gain in GDP comes at the cost of lower tax revenues. Conversely, a loss in GDP is generally accompanied by higher tax revenues. As previously noted, this is because changes in the level of distortionary taxation tend to outweigh all other effects at the country level when government budgets are balanced by adjusting income transfers to offset changes in tax revenues.

Table 3. Individual country effects of full harmonisation at unweighted averages

\begin{tabular}{|c|c|c|c|c|c|}
\hline Member state & $\begin{array}{c}\text { Change in } \\
\text { GDP } \\
(\%)\end{array}$ & $\begin{array}{l}\text { Change in } \\
\text { welfare } \\
\text { (\% of GDP) }\end{array}$ & $\begin{array}{l}\text { Change in } \\
\text { total tax } \\
\text { revenue } \\
\text { (\% of GDP) }\end{array}$ & $\begin{array}{l}\text { Change in } \\
\text { corporate tax } \\
\text { rate } \\
\text { (\%-points) }\end{array}$ & $\begin{array}{c}\text { Change in } \\
\text { capital } \\
\text { allowance rate } \\
\text { (\%) }\end{array}$ \\
\hline Austria & 0.7 & 0.2 & -0.3 & -6.8 & 0.1 \\
\hline Belgium & 3.2 & 0.6 & -0.2 & -6.8 & 43.2 \\
\hline Denmark & 1.8 & 0.3 & -0.2 & -2.8 & 57.4 \\
\hline Finland & 1.6 & 0.2 & -0.3 & -1.8 & 73.9 \\
\hline France & 2.4 & 0.4 & -0.4 & -7.8 & 36.2 \\
\hline Germany & -1.6 & 0.1 & 0.2 & -10.8 & -54.6 \\
\hline Greece & 1.1 & 0.2 & -0.2 & -7.8 & -3.2 \\
\hline Ireland & -1.0 & -0.1 & 0.7 & 14.7 & 7.8 \\
\hline Italy & 1.4 & 0.2 & -0.5 & -5.8 & 23.5 \\
\hline Luxembourg & 3.7 & 0.6 & -1.3 & -3.2 & 201.7 \\
\hline Netherlands & 2.7 & 0.4 & -0.6 & -7.3 & 52.5 \\
\hline Portugal & 1.2 & 0.2 & -0.4 & -0.3 & 53.8 \\
\hline Spain & 0.4 & 0.3 & -0.1 & -7.8 & -11.0 \\
\hline Sweden & 1.1 & 0.2 & -0.2 & -0.8 & 44.5 \\
\hline UK & 2.2 & 0.3 & -0.8 & -2.8 & 122.1 \\
\hline Cyprus & -1.2 & -0.1 & 1.0 & 12.2 & -12.7 \\
\hline Czech Rep. & 2.3 & 0.2 & -0.8 & -0.8 & 134.5 \\
\hline Estonia & -2.4 & -0.1 & 1.3 & 1.2 & -73.4 \\
\hline Hungary & 0.5 & -0.1 & 0.0 & 11.2 & 162.7 \\
\hline Latvia & 0.1 & 0.0 & 0.4 & 12.2 & 98.4 \\
\hline Lithuania & 0.4 & 0.0 & 0.3 & 12.2 & 176.1 \\
\hline Malta & -1.1 & 0.0 & 0.0 & -7.8 & -40.4 \\
\hline Poland & -1.1 & -0.2 & 0.6 & 8.2 & -24.0 \\
\hline Slovak Rep. & -0.7 & -0.1 & 0.5 & 8.2 & 1.9 \\
\hline Slovenia & -1.7 & -0.1 & 0.5 & 2.2 & -48.2 \\
\hline EU25 & 0.8 & 0.2 & -0.2 & & \\
\hline
\end{tabular}

Note: The harmonised corporate tax rate is $27.2 \%$.

Government budgets are balanced by adjusting income transfers.

Source: CETAX simulations. 
This analysis highlights some fundamental dilemmas for any policy of tax harmonisation. On the one hand harmonisation cannot generate any aggregate efficiency gain from an improved allocation of capital unless national tax systems differ from the outset. On the other hand these initial differences in national tax policies inevitably mean that tax harmonisation creates losers as well as winners. As long as decisions on EU tax harmonisation require unanimity among the Member States, it is thus inconceivable that any agreement could be reached without some kind of compensating transfers from the winning to the losing countries.

But this points to another dilemma: Any compensation scheme must identify winners and losers. If losers are defined as those countries where tax revenues fall as a result of harmonisation, the implication would be that countries suffering drops in GDP (and welfare) would compensate countries with gains in GDP (and welfare). If, on the other hand, losers are defined as those countries where GDP decreases as a result of the reforms, the implication would be that countries suffering drops in tax revenues would compensate countries with gains in tax revenues. Both options will prove hard to accept for policy makers.

A further dilemma arises from the fact that the (sometimes significant) changes in Member State revenues implied by tax harmonisation can hardly be absorbed without a noticeable impact on the internal distribution of income and welfare within Member States. Presumably, this makes tax harmonisation even more controversial.

\subsection{Enhanced Cooperation versus full harmonisation}

The analysis above suggests that although the aggregate efficiency gain from tax harmonisation will be smaller, the gain will be less unevenly distributed the greater the similarity between the initial national tax systems. Moreover, harmonisation will generate savings on compliance and administration costs that are not included in our model analysis, ${ }^{12}$ and these gains will be shared by all countries engaging in harmonisation. Because of the more equal distribution of gains, it seems more likely that a more homogeneous group of countries like the members of the

\footnotetext{
${ }^{12}$ For example, when statutory corporate tax rates are equalized across the EU, the need to enforce complex transfer pricing rules for transactions within the Union essentially vanishes.
} 
euro zone could reach an agreement on tax harmonisation. This is the rationale for considering the effects of Enhanced Cooperation involving corporate tax harmonisation within the euro zone.

Figures 3 and 4 confirm that the dispersion of the net gains from harmonisation of tax rates as well as tax bases would indeed be smaller within the euro zone than within the EU25. However, the difference in the degree of dispersion is seen to be relatively small, and the simulations underlying Figures 3 and 4 reveal that the difference between harmonisation at the unweighted or weighted average corporate tax rate and tax base is more pronounced in the case of Enhanced Cooperation, compared to the scenario with full harmonisation. In case of Enhanced Cooperation for the euro zone, harmonisation at unweighted averages tends to imply losses in GDP and gains in tax revenues, whereas harmonisation at weighted averages yields opposite results.

Figure 3. Difference between largest and smallest impact (unweighted averages)

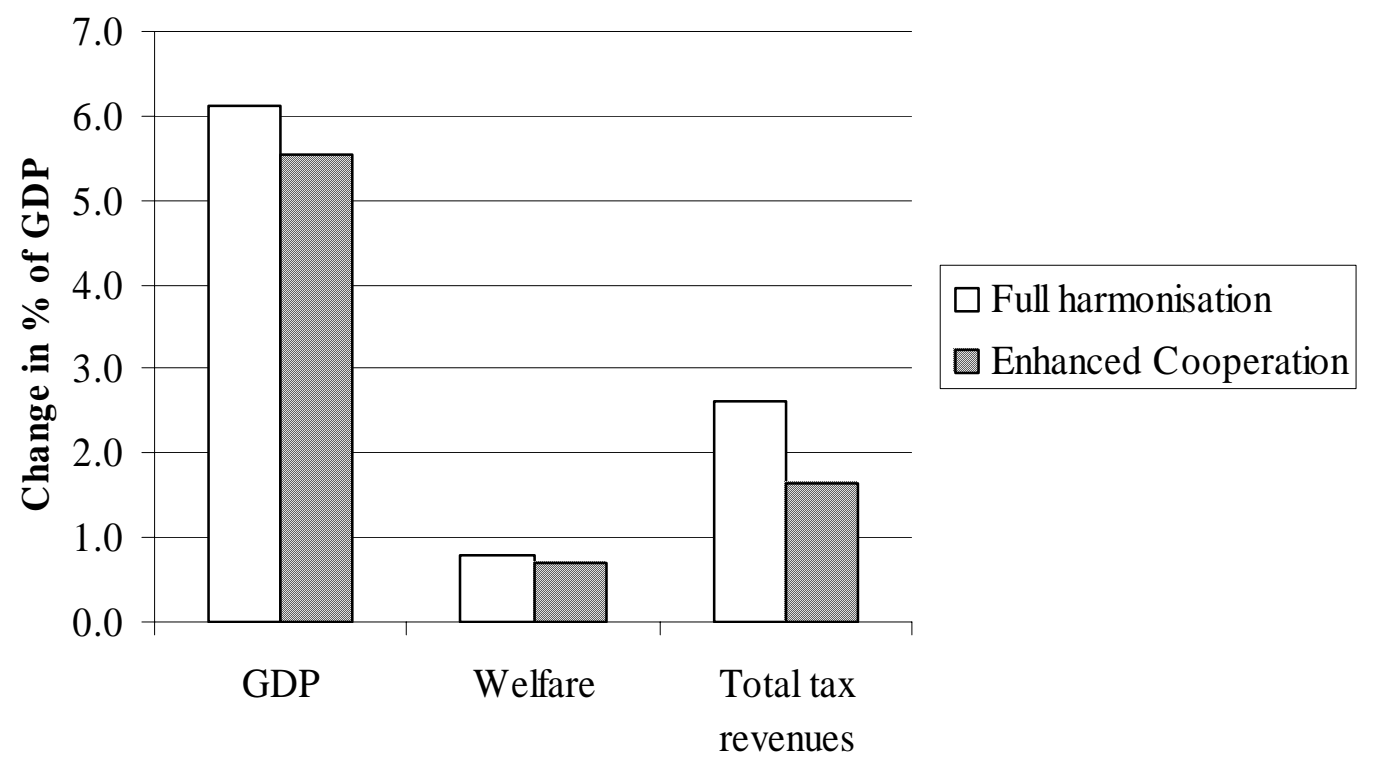


Figure 4. Difference between largest and smallest impact (weighted averages)

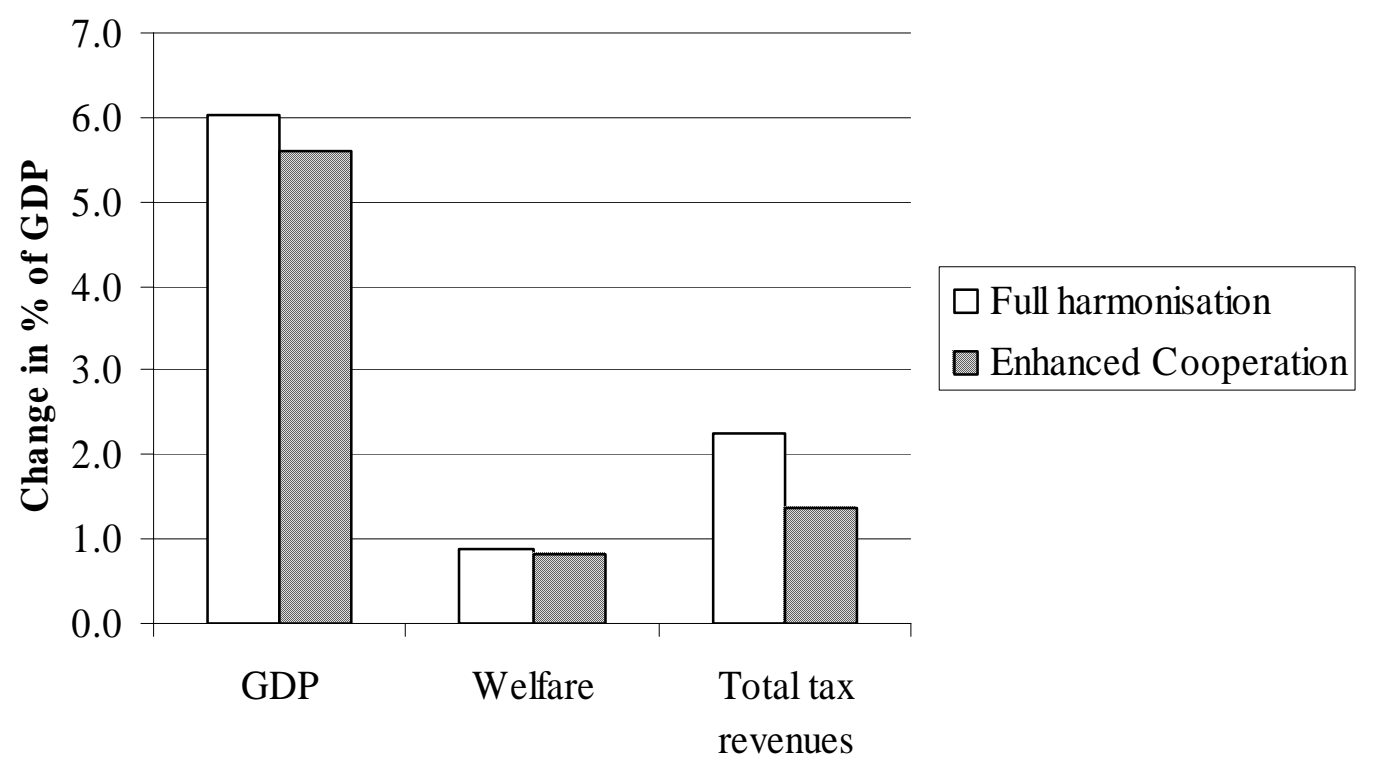

The differences are to a large extent driven by individual country impacts, most notably by the impact on Germany, which has the largest economy in the EU. As previously noted, the German economy is an outlier in the sense that the tax base is very narrow compared to other EU15 Member States. When harmonisation takes place at the unweighted average tax rate and tax base, the German tax base is drastically increased, leading to a sharp increase in the total corporate tax burden and an accompanying fall in economic activity. Because Germany constitutes around one fifth of the total EU economy, this effect has a strong impact on the results for Enhanced Cooperation at unweighted averages.

Against this background, harmonisation at the weighted average tax rate and base may seem a tempting alternative for Enhanced Cooperation, since it involves a smaller dispersion of the effects of harmonisation. However, such a scenario implies that the rules for determining the harmonised tax base must be heavily oriented towards replicating the effects of German tax legislation.

\subsection{Tax base harmonisation versus full harmonisation}

The economic effects of tax base harmonisation are conceptually different from full harmonisation. When only the tax base is harmonised, substantial differences in effective corporate tax rates will remain. In fact, if countries with 
relatively broad tax bases tend to have relatively low tax rates, and vice versa, tax base harmonisation may lead to an increase in effective tax rate differences. The implication is that cross-country distortions to investment decisions may remain or even increase, thereby eliminating any gains from the improved capital allocation that follows full harmonisation.

Still, tax base harmonisation can result in economic gains as illustrated in Figure 1 and Figure 2. The gains in GDP and welfare are primarily a result of the overall drop in taxation. The decrease in tax revenues is the effect of harmonising only one of the two components determining corporate tax revenues (the other component is the statutory tax rate). Specifically, the drop in aggregate revenue reflects that it is mainly the small EU countries which are forced to broaden their tax bases whereas most of the large Member States (except Germany) must increase their capital allowance rates. When government budgets are balanced by adjusting income transfers, lower taxation increases investment and economic activity.

As was the case for full harmonisation, individual country effects are significantly larger than the aggregate effect for the EU as a whole. There are still clear winners and losers from harmonisation, and the span between the biggest positive and negative outcome is considerable (see Tables A.3 and A.4 in the appendix).

An important motivation for harmonising tax bases is to reduce tax compliance costs for firms with multinational operations in the Internal Market. The costs of complying with the corporate tax code - which are not included in our model - are generally estimated to amount to $2-4 \%$ of corporate tax revenues (Lanno \& Levin, 2002). However, solid evidence on compliance costs is scarce and the estimated magnitude of these costs differs quite a lot across studies. ${ }^{13}$ In recognition of the problem, the Commission recently launched a comprehensive survey of the compliance costs associated with company taxation and VAT. Analysis of quantitative estimates provided by 700 companies in 14 EU Member States suggests that compliance costs in the EU amount to $1.9 \%$ of taxes paid.

\footnotetext{
${ }^{13}$ Slemrod and Blumenthal (1993) have estimated tax compliance costs for the USA, Pope et al (1990) for Australia, Sandford (1995) for the United Kingdom, Erard (1997) for Canada, and Allers (1994) for the Netherlands. The Ruding Committee has surveyed EC and EFTA countries (European Commission, 1992).
} 
Table 3 implicitly also provides insights into the issue of compliance costs. The large adjustments to tax bases that sometimes are required by harmonisation indicate that existing rules for calculating taxable corporate income differ significantly across countries. This suggests that tax base harmonisation could result in sizeable reductions in compliance costs. The present study may therefore underestimate the gains from tax coordination. However, as long as statutory tax rate differentials remain, multinationals will have an incentive to engage in international profit-shifting via transfer-pricing, and hence the present complex transfer-pricing regulations will have to be maintained, at least as long as the corporate tax base is allocated across countries by the method of separate accounting. ${ }^{14}$ The saving of compliance costs would therefore be smaller under tax base harmonisation than under full harmonisation.

\subsection{Budget balancing through adjustment of the labour income tax}

Coordination of corporate taxes can have substantial effects on tax revenues. Full harmonisation yields significant revenue gains in some countries and considerable losses in others (see Table 3). The large effects imply that corporate tax cooperation is likely to be bundled with reforms of other parts of the tax system.

Most countries lose revenues. If labour income taxes are used instead of income transfers to balance the government budgets, these countries experience smaller gains in GDP and welfare and some even experience a small loss in GDP, as shown in Table 4.

Some countries, including Germany and Estonia, gain revenues from a full harmonisation of corporate taxation (again, see Table 3). The welfare impacts are positive in some cases, e.g. Germany, as the tax system is now less distortionary, and negative in other cases, e.g., Estonia, where distortions have increased. All of these countries experience gains, however, if they use the larger corporate tax revenues to reduce labour income taxes. Unemployment rates decrease accordingly.

The EU as a whole continues to gain from tax coordination if labour income taxes are used to keep government budgets balanced, as shown in Figure 5.

\footnotetext{
${ }^{14}$ In principle the transfer-pricing problem could be solved if the corporate tax base were apportioned by a fixed formula, as proposed by the European Commission (2001a). However, formula apportionment has its own problems, as discussed by Sørensen (2004a).
} 
Table 4. Full harmonisation with budget neutral tax revenues

\begin{tabular}{|c|c|c|c|c|}
\hline Member state & $\begin{array}{l}\text { Change in } \\
\text { GDP } \\
(\%)\end{array}$ & $\begin{array}{l}\text { Change in } \\
\text { welfare } \\
\text { (\% of GDP) }\end{array}$ & $\begin{array}{l}\text { Change in } \\
\text { total tax } \\
\text { revenue } \\
\text { (\% of GDP) }\end{array}$ & $\begin{array}{l}\text { Change in } \\
\text { unemployment } \\
\text { (\%-points) }\end{array}$ \\
\hline Austria & 0.0 & 0.0 & 0.0 & 0.2 \\
\hline Belgium & 1.3 & 0.4 & 0.0 & 0.3 \\
\hline Denmark & 1.3 & 0.1 & 0.0 & 0.2 \\
\hline Finland & 1.2 & 0.1 & 0.0 & 0.2 \\
\hline France & 0.6 & -0.1 & 0.0 & 0.7 \\
\hline Germany & -2.1 & 0.2 & 0.0 & -0.3 \\
\hline Greece & -0.2 & 0.2 & 0.0 & 0.1 \\
\hline Ireland & 0.0 & 0.1 & 0.0 & -0.2 \\
\hline Italy & 0.6 & 0.0 & 0.1 & 0.0 \\
\hline Luxembourg & 3.0 & 0.3 & 0.0 & 0.2 \\
\hline Netherlands & 1.5 & 0.1 & 0.0 & 0.2 \\
\hline Portugal & 1.0 & 0.1 & 0.0 & 0.1 \\
\hline Spain & -0.4 & 0.2 & 0.0 & 0.1 \\
\hline Sweden & 0.9 & 0.1 & 0.0 & 0.0 \\
\hline UK & 1.7 & 0.1 & 0.0 & 0.1 \\
\hline Cyprus & -0.2 & 0.0 & 0.0 & -0.1 \\
\hline Czech Rep. & 1.7 & 0.0 & 0.0 & 0.2 \\
\hline Estonia & -1.1 & 0.2 & 0.0 & -0.3 \\
\hline Hungary & 0.9 & -0.1 & 0.0 & 0.0 \\
\hline Latvia & 0.6 & 0.1 & 0.0 & -0.1 \\
\hline Lithuania & 0.8 & 0.1 & 0.0 & -0.1 \\
\hline Malta & -1.4 & 0.0 & -0.1 & 0.0 \\
\hline Poland & -0.2 & 0.2 & 0.0 & -0.4 \\
\hline Slovak Rep. & 0.0 & 0.0 & 0.0 & -0.1 \\
\hline Slovenia & -0.8 & 0.2 & 0.0 & -0.3 \\
\hline EU25 & 0.6 & 0.1 & 0.0 & \\
\hline
\end{tabular}

Note: The tax bases and rates are harmonised at the unweighted EU25 average.

Government budgets are balanced by adjusting the labour income tax rates.

Source: CETAX simulations. 
Figure 5. Budget balancing through adjustment of the labour income tax versus adjustment of transfers (full harmonisation at unweighted averages)

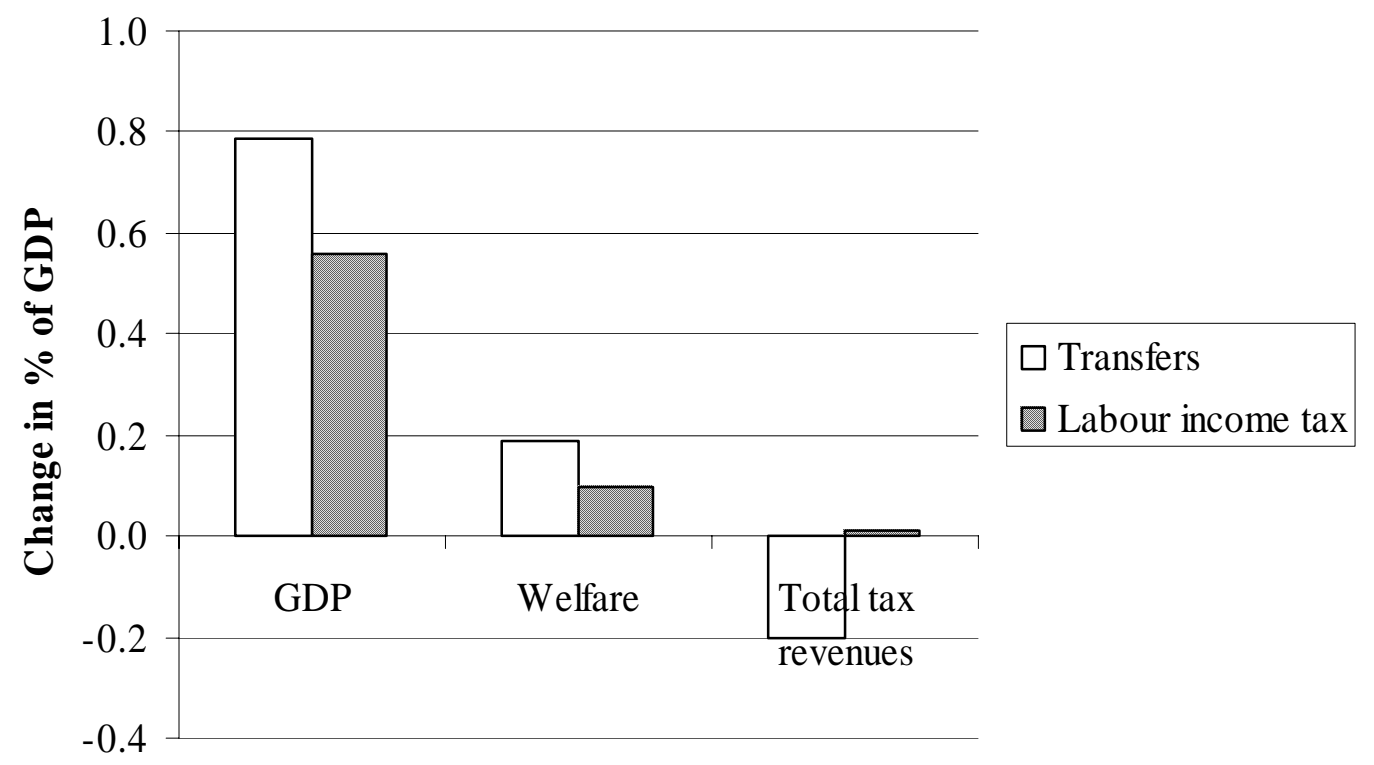

\subsection{A summary comparison of policy scenarios}

This section provides summary tables with results from the different scenarios. Table 5 compares full harmonisation to tax base harmonisation, assuming that coordination involves all of the EU25 countries. The table shows that full harmonisation at weighted averages is the most attractive policy option for corporate tax coordination if the overall level of taxation is to be kept unchanged for the EU as a whole. Larger gains can be achieved only by lower (effective) tax rates resulting in lower tax revenues.

Table 5. Comparison of full and base harmonisation

\begin{tabular}{lrrrr}
\hline & \multicolumn{2}{c}{ Full harmonisation } & \multicolumn{2}{c}{ Base harmonisation } \\
& $\begin{array}{c}\text { Unweighted } \\
\text { averages }\end{array}$ & $\begin{array}{c}\text { Weighted } \\
\text { averages }\end{array}$ & $\begin{array}{c}\text { Unweighted } \\
\text { averages }\end{array}$ & $\begin{array}{c}\text { Weighted } \\
\text { averages }\end{array}$ \\
\hline GDP (\%) & 0.8 & 0.4 & 0.2 & 0.3 \\
Welfare (\% of GDP) & 0.2 & 0.1 & 0.0 & 0.1 \\
Total tax revenues (\% of GDP) & -0.2 & 0.0 & -0.1 & -0.1 \\
\hline
\end{tabular}

Note: Government budgets are balanced by adjusting income transfers

Source: CETAX simulations. 
The picture is a bit more complex for the case of Enhanced Cooperation, but the basic policy conclusion remains the same. We have so far assumed that Enhanced Cooperation would involve full harmonisation of tax bases and tax rates within the euro zone, but the euro countries might of course choose to cooperate only on tax base harmonisation. Figure 6 illustrates the difference between these alternatives. The figure shows that only full harmonisation at weighted averages consistently results in both GDP and welfare gains.

Figure 6. Comparison of full and base harmonisation (Enhanced Cooperation)

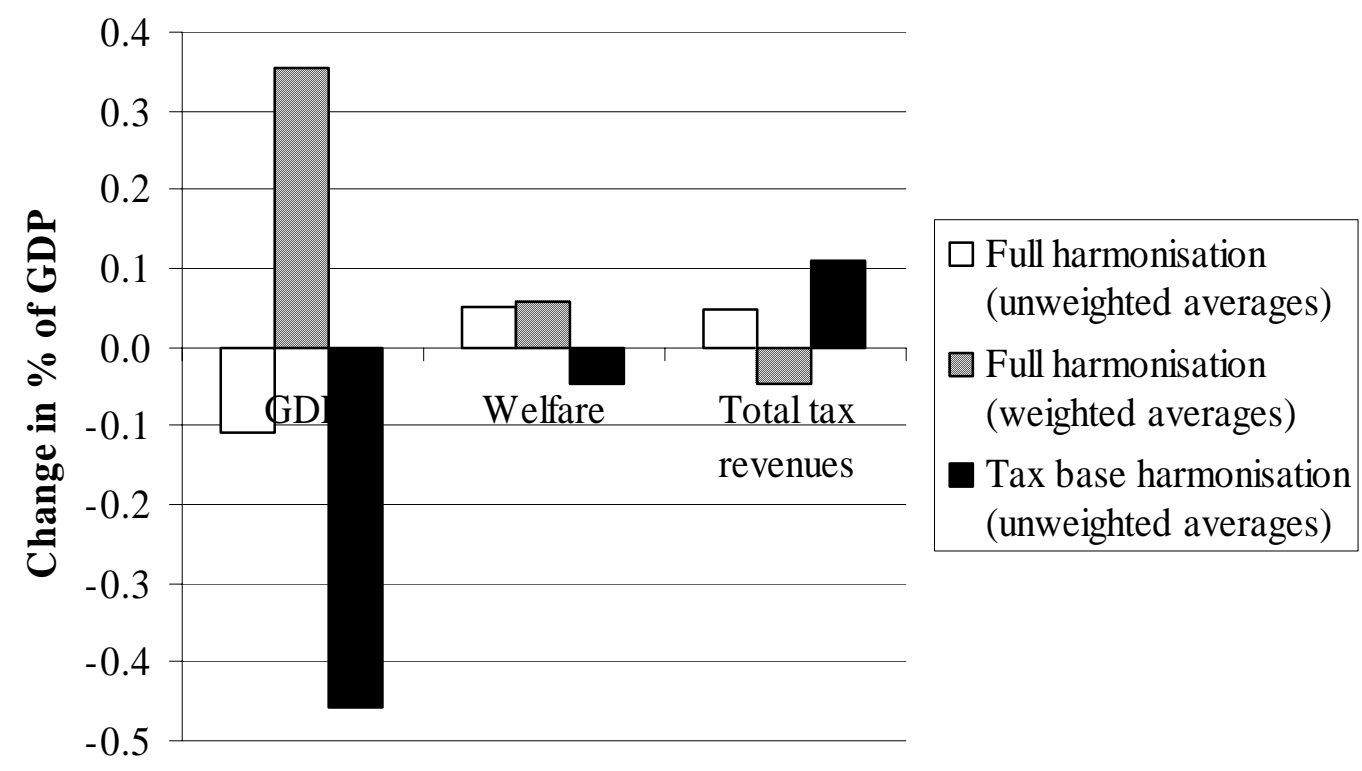

In summary, it appears that full harmonisation of both the corporate tax rate and the corporate tax base, at the weighted averages of current rates and bases, is the most interesting option from an economic point of view. As previously noted, this is because full harmonisation at weighted averages comes closest to realizing the benefits from improved capital allocation without affecting the level of taxation.

\section{Conclusions and caveats}

This study offers new insights into the issue of corporate tax coordination in the European Union. In particular, it suggests that the aggregate efficiency gains from corporate tax harmonisation are likely to be rather small, because many 
important forms of saving and investment outside the corporate sector would continue to be subject to widely diverging national tax rules, just as personal tax rates on corporate source income would continue to differ. Indeed, according to the estimates presented in Sørensen (2001), the efficiency gain from a full harmonisation of all taxes on capital income in the EU could be about four times as large as the estimated gain from corporate tax harmonisation in the present study. This underscores the importance of allowing for the fact that the corporation tax is only one component in the wider complex of capital income taxes.

Moreover, our study points to some fundamental dilemmas raised by any policy involving full or partial harmonisation of national corporate tax systems. The allocation gains from harmonisation arise because national tax systems differ from the outset, but these very differences also imply that some countries are bound to lose from harmonisation. Hence agreement on harmonisation is unlikely unless the gainers are willing to somehow compensate the losers. But here the next dilemma arises: if losers are defined as those countries where tax revenues fall as a result of harmonisation, the implication would be that countries suffering drops in GDP would compensate countries with gains in GDP. If, on the other hand, losers are defined as those countries where GDP decreases as a result of harmonisation, countries suffering drops in tax revenues would have to compensate countries with gains in tax revenues. In both cases it seems unlikely that a compensation scheme would be acceptable to all Member States.

The large and diverse country effects of full harmonisation suggest that Enhanced Cooperation for a subset of the Member States may be the most realistic (or least unlikely) route towards tax coordination. Both full harmonisation and tax base harmonisation across the EU as a whole seems politically infeasible given the unanimity requirement on tax policy decisions. Coordination among a subset of relatively homogeneous Member States will lead to less radical policy changes, but also to smaller gains. Yet Enhanced Cooperation could constitute a first step towards corporate tax coordination. Indeed, Tables A.5 and A.6 in the appendix indicate that only Germany and Ireland would lose from Enhanced Cooperation on corporate taxation within the euro zone.

The unanimity rule for tax policy decisions implies that all countries have an equal say. Given the general tendency of governments to favour national sovereignty 
on corporate taxation, the unanimity rule makes harmonisation at a level close to the unweighted average of current systems most relevant.

Harmonisation at the weighted average of current tax rates and tax bases implies that large economies are given more influence in determining the harmonised tax base and tax rate. The present study suggests that this makes more economic sense, but it also implies a larger dent in the national sovereignty of small Member States, representing yet another dilemma for tax coordination.

Although the choice of the specific level of harmonisation may seem a purely technical issue, the policy implications are profound. Our study reveals a large difference between harmonisation at the unweighted and weighted averages of current corporate tax rates and bases. For Enhanced Cooperation on full harmonisation, the difference is a question of either aggregate gains or aggregate losses. Enhanced Cooperation involving a smaller and more homogeneous group of countries may therefore be preferred because of the need for very specific agreements on the details of tax coordination.

The present study has focused on the static allocative gains from eliminating existing corporate tax differentials within the EU. It suggests that these gains will be rather small. However, tax harmonisation may create other types of gain that are not included in our analysis.

First, harmonisation will reduce the costs of tax compliance and tax administration, as we have already mentioned.

Second, even if there were no initial differences in national tax systems and hence no potential efficiency gain from a better cross-country allocation of capital, tax coordination might still generate a welfare gain by eliminating corporate tax competition among EU Member States. In particular, many scholars have emphasized that tax competition will tend to cause an under-provision of public goods or an undesirable shift of the tax burden from capital to labour. ${ }^{15}$ On the other hand, many observers and policy makers have argued that tax competition has the beneficial effect of improving public sector efficiency. But even if this is the case, some amount of tax coordination (e.g. a required minimum effective corporate tax

${ }^{15}$ See the literature surveys by Wilson (1999) and Zodrow (2003). 
rate) is still likely to be welfare-improving by offsetting the tendency towards underprovision of public goods, as shown by Eggert and Sørensen (2006).

Third, and related to the previous point, unfettered tax competition may also constrain the ability of governments to engage in redistributive taxation. For egalitarian governments, the resulting increase in inequality may entail a social welfare cost which could be avoided through tax coordination (see Sørensen (2004c) for an attempt to quantify this type of gain from coordination). Again, our analysis does not account for such an effect of tax coordination.

Still, by pointing to some fundamental dilemmas for international tax coordination, the present study may help to explain why EU Member States have been so reluctant to cooperate on tax policy. 


\section{Appendix: Detailed tables}

Table A.1. Full harmonisation at unweighted averages

\begin{tabular}{|c|c|c|c|c|c|}
\hline Member state & $\begin{array}{l}\text { Change in } \\
\text { GDP } \\
(\%)\end{array}$ & $\begin{array}{l}\text { Change in } \\
\text { welfare } \\
\text { (\% of GDP) }\end{array}$ & $\begin{array}{l}\text { Change in } \\
\text { total tax } \\
\text { revenue } \\
\text { (\% of GDP) }\end{array}$ & $\begin{array}{c}\text { Change in } \\
\text { corporate tax } \\
\text { rate } \\
\text { (\%-points) }\end{array}$ & $\begin{array}{c}\text { Change in } \\
\text { capital } \\
\text { allowance rate } \\
(\%)\end{array}$ \\
\hline Austria & 0.7 & 0.2 & -0.3 & -6.8 & 0.1 \\
\hline Belgium & 3.2 & 0.6 & -0.2 & -6.8 & 43.2 \\
\hline Denmark & 1.8 & 0.3 & -0.2 & -2.8 & 57.4 \\
\hline Finland & 1.6 & 0.2 & -0.3 & -1.8 & 73.9 \\
\hline France & 2.4 & 0.4 & -0.4 & -7.8 & 36.2 \\
\hline Germany & -1.6 & 0.1 & 0.2 & -10.8 & -54.6 \\
\hline Greece & 1.1 & 0.2 & -0.2 & -7.8 & -3.2 \\
\hline Ireland & -1.0 & -0.1 & 0.7 & 14.7 & 7.8 \\
\hline Italy & 1.4 & 0.2 & -0.5 & -5.8 & 23.5 \\
\hline Luxembourg & 3.7 & 0.6 & -1.3 & -3.2 & 201.7 \\
\hline Netherlands & 2.7 & 0.4 & -0.6 & -7.3 & 52.5 \\
\hline Portugal & 1.2 & 0.2 & -0.4 & -0.3 & 53.8 \\
\hline Spain & 0.4 & 0.3 & -0.1 & -7.8 & -11.0 \\
\hline Sweden & 1.1 & 0.2 & -0.2 & -0.8 & 44.5 \\
\hline UK & 2.2 & 0.3 & -0.8 & -2.8 & 122.1 \\
\hline Cyprus & -1.2 & -0.1 & 1.0 & 12.2 & -12.7 \\
\hline Czech Rep. & 2.3 & 0.2 & -0.8 & -0.8 & 134.5 \\
\hline Estonia & -2.4 & -0.1 & 1.3 & 1.2 & -73.4 \\
\hline Hungary & 0.5 & -0.1 & 0.0 & 11.2 & 162.7 \\
\hline Latvia & 0.1 & 0.0 & 0.4 & 12.2 & 98.4 \\
\hline Lithuania & 0.4 & 0.0 & 0.3 & 12.2 & 176.1 \\
\hline Malta & -1.1 & 0.0 & 0.0 & -7.8 & -40.4 \\
\hline Poland & -1.1 & -0.2 & 0.6 & 8.2 & -24.0 \\
\hline Slovak Rep. & -0.7 & -0.1 & 0.5 & 8.2 & 1.9 \\
\hline Slovenia & -1.7 & -0.1 & 0.5 & 2.2 & -48.2 \\
\hline EU25 & 0.8 & 0.2 & -0.2 & & \\
\hline
\end{tabular}

Note: The harmonised corporate tax rate is $27.2 \%$

Government budgets are balanced by adjusting income transfers.

Source: CETAX simulations. 
Table A.2. Full harmonisation at weighted averages

\begin{tabular}{|c|c|c|c|c|c|}
\hline Member state & $\begin{array}{l}\text { Change in } \\
\text { GDP } \\
(\%)\end{array}$ & $\begin{array}{l}\text { Change in } \\
\text { welfare } \\
\text { (\% of GDP) }\end{array}$ & $\begin{array}{l}\text { Change in } \\
\text { total tax } \\
\text { revenue } \\
\text { (\% of GDP) }\end{array}$ & $\begin{array}{c}\text { Change in } \\
\text { corporate tax } \\
\text { rate } \\
\text { (\%-points) }\end{array}$ & $\begin{array}{c}\text { Change in } \\
\text { capital } \\
\text { allowance rate } \\
(\%)\end{array}$ \\
\hline Austria & 0.4 & 0.1 & -0.1 & -1.4 & 5.6 \\
\hline Belgium & 2.4 & 0.5 & -0.1 & -1.4 & 51.2 \\
\hline Denmark & 1.3 & 0.2 & -0.1 & 2.6 & 66.1 \\
\hline Finland & 1.2 & 0.1 & -0.1 & 3.6 & 83.5 \\
\hline France & 2.0 & 0.3 & -0.3 & -2.4 & 43.7 \\
\hline Germany & -2.1 & -0.1 & 0.4 & -5.4 & -52.1 \\
\hline Greece & 0.6 & 0.1 & 0.0 & -2.4 & 2.1 \\
\hline Ireland & -1.3 & -0.2 & 0.8 & 20.1 & 13.7 \\
\hline Italy & 1.1 & 0.1 & -0.3 & -0.4 & 30.3 \\
\hline Luxembourg & 3.4 & 0.5 & -0.7 & 2.2 & 218.3 \\
\hline Netherlands & 2.3 & 0.3 & -0.4 & -1.9 & 60.9 \\
\hline Portugal & 0.8 & 0.1 & -0.2 & 5.1 & 62.3 \\
\hline Spain & 0.0 & 0.1 & 0.0 & -2.4 & -6.1 \\
\hline Sweden & 0.7 & 0.0 & -0.1 & 4.6 & 52.5 \\
\hline UK & 1.9 & 0.2 & -0.6 & 2.6 & 134.3 \\
\hline Cyprus & -1.4 & -0.2 & 1.3 & 17.3 & -7.8 \\
\hline Czech Rep. & 2.0 & 0.1 & -0.5 & 4.5 & 144.4 \\
\hline Estonia & -2.6 & -0.1 & 1.5 & 6.5 & -71.3 \\
\hline Hungary & 0.3 & -0.2 & 0.1 & 16.2 & 173.6 \\
\hline Latvia & -0.2 & 0.0 & 0.7 & 17.3 & 107.7 \\
\hline Lithuania & 0.1 & -0.1 & 0.5 & 17.5 & 190.5 \\
\hline Malta & -1.4 & -0.1 & 0.3 & -2.4 & -36.9 \\
\hline Poland & -1.3 & -0.3 & 0.7 & 13.5 & -19.7 \\
\hline Slovak Rep. & -0.9 & -0.2 & 0.8 & 13.5 & 7.5 \\
\hline Slovenia & -1.9 & -0.2 & 0.7 & 7.4 & -44.4 \\
\hline EU25 & 0.4 & 0.1 & 0.0 & & \\
\hline
\end{tabular}

Note: The harmonised corporate tax rate is $32.6 \%$.

Government budgets are balanced by adjusting income transfers.

Source: CETAX simulations. 
Table A.3. Tax base harmonisation at unweighted averages

\begin{tabular}{|c|c|c|c|c|c|}
\hline Member state & $\begin{array}{l}\text { Change in } \\
\text { GDP } \\
(\%)\end{array}$ & $\begin{array}{l}\text { Change in } \\
\text { welfare } \\
\text { (\% of GDP) }\end{array}$ & $\begin{array}{l}\text { Change in } \\
\text { total tax } \\
\text { revenue } \\
\text { (\% of GDP) }\end{array}$ & $\begin{array}{c}\text { Change in } \\
\text { corporate tax } \\
\text { rate } \\
\text { (\%-points) }\end{array}$ & $\begin{array}{c}\text { Change in } \\
\text { capital } \\
\text { allowance rate } \\
\text { (\%) }\end{array}$ \\
\hline Austria & 0.0 & 0.0 & 0.0 & & 0.1 \\
\hline Belgium & 1.8 & 0.4 & -0.1 & & 43.2 \\
\hline Denmark & 1.5 & 0.3 & -0.1 & & 57.4 \\
\hline Finland & 1.5 & 0.2 & -0.2 & & 73.9 \\
\hline France & 1.4 & 0.1 & -0.2 & & 36.2 \\
\hline Germany & -3.2 & -0.3 & 0.6 & & -54.6 \\
\hline Greece & -0.2 & 0.0 & 0.0 & & -3.2 \\
\hline Ireland & 0.1 & 0.0 & 0.0 & & 7.8 \\
\hline Italy & 0.8 & 0.1 & -0.2 & & 23.5 \\
\hline Luxembourg & 3.4 & 0.5 & -0.9 & & 201.7 \\
\hline Netherlands & 1.8 & 0.2 & -0.3 & & 52.5 \\
\hline Portugal & 1.3 & 0.2 & -0.3 & & 53.8 \\
\hline Spain & -0.6 & -0.1 & 0.1 & & -11.0 \\
\hline Sweden & 1.1 & 0.1 & -0.1 & & 44.5 \\
\hline UK & 2.1 & 0.2 & -0.6 & & 122.1 \\
\hline Cyprus & -0.2 & 0.0 & 0.1 & & -12.7 \\
\hline Czech Rep. & 2.3 & 0.2 & -0.7 & & 134.5 \\
\hline Estonia & -0.9 & 0.0 & -0.3 & & -73.4 \\
\hline Hungary & 1.3 & 0.1 & -0.4 & & 162.8 \\
\hline Latvia & 0.9 & 0.0 & -0.4 & & 98.4 \\
\hline Lithuania & 1.3 & 0.1 & -0.5 & & 176.2 \\
\hline Malta & -1.8 & -0.1 & 0.5 & & -40.4 \\
\hline Poland & -0.4 & 0.0 & 0.1 & & -24.0 \\
\hline Slovak Rep. & 0.0 & 0.0 & 0.0 & & 1.9 \\
\hline Slovenia & -1.5 & 0.0 & 0.4 & & -48.2 \\
\hline EU25 & 0.2 & 0.0 & -0.1 & & \\
\hline
\end{tabular}

Note: Statutory corporate tax rates are unchanged.

Government budgets are balanced by adjusting income transfers.

Source: CETAX simulations. 
Table A.4. Tax base harmonisation at weighted averages

\begin{tabular}{|c|c|c|c|c|c|}
\hline Member state & $\begin{array}{l}\text { Change in } \\
\text { GDP } \\
(\%)\end{array}$ & $\begin{array}{l}\text { Change in } \\
\text { welfare } \\
\text { (\% of GDP) }\end{array}$ & $\begin{array}{l}\text { Change in } \\
\text { total tax } \\
\text { revenue } \\
\text { (\% of GDP) }\end{array}$ & $\begin{array}{c}\text { Change in } \\
\text { corporate tax } \\
\text { rate } \\
\text { (\%-points) }\end{array}$ & $\begin{array}{c}\text { Change in } \\
\text { capital } \\
\text { allowance rate } \\
\text { (\%) }\end{array}$ \\
\hline Austria & 0.2 & 0.0 & 0.0 & & 5.6 \\
\hline Belgium & 2.0 & 0.4 & -0.1 & & 51.2 \\
\hline Denmark & 1.7 & 0.3 & -0.1 & & 66.1 \\
\hline Finland & 1.7 & 0.2 & -0.2 & & 83.5 \\
\hline France & 1.6 & 0.1 & -0.3 & & 43.7 \\
\hline Germany & -3.0 & -0.3 & 0.6 & & -52.1 \\
\hline Greece & 0.0 & 0.0 & 0.0 & & 2.1 \\
\hline Ireland & 0.1 & 0.0 & 0.0 & & 13.7 \\
\hline Italy & 1.0 & 0.1 & -0.2 & & 30.3 \\
\hline Luxembourg & 3.6 & 0.6 & -1.0 & & 218.3 \\
\hline Netherlands & 2.0 & 0.2 & -0.3 & & 60.9 \\
\hline Portugal & 1.4 & 0.2 & -0.4 & & 62.3 \\
\hline Spain & -0.3 & 0.0 & 0.1 & & -6.1 \\
\hline Sweden & 1.2 & 0.1 & -0.2 & & 52.5 \\
\hline UK & 2.2 & 0.3 & -0.7 & & 134.3 \\
\hline Cyprus & -0.1 & 0.0 & 0.1 & & -7.9 \\
\hline Czech Rep. & 2.4 & 0.2 & -0.8 & & 147.5 \\
\hline Estonia & -0.9 & 0.0 & -0.3 & & -71.9 \\
\hline Hungary & 1.4 & 0.1 & -0.4 & & 177.3 \\
\hline Latvia & 0.9 & 0.1 & -0.4 & & 109.3 \\
\hline Lithuania & 1.4 & 0.1 & -0.5 & & 191.4 \\
\hline Malta & -1.7 & -0.1 & 0.5 & & -37.1 \\
\hline Poland & -0.4 & 0.0 & 0.1 & & -19.8 \\
\hline Slovak Rep. & 0.1 & 0.0 & 0.0 & & 7.5 \\
\hline Slovenia & -1.3 & 0.0 & 0.4 & & -45.3 \\
\hline EU25 & 0.3 & 0.1 & -0.1 & & \\
\hline
\end{tabular}

Note: Statutory corporate tax rates are unchanged.

Government budgets are balanced by adjusting income transfers.

Source: CETAX simulations. 
Table A.5. Enhanced Cooperation at unweighted averages

\begin{tabular}{|c|c|c|c|c|c|}
\hline Member state & $\begin{array}{c}\text { Change in } \\
\text { GDP } \\
(\%)\end{array}$ & $\begin{array}{l}\text { Change in } \\
\text { welfare } \\
\text { (\% of GDP) }\end{array}$ & $\begin{array}{l}\text { Change in } \\
\text { total tax } \\
\text { revenue } \\
\text { (\% of GDP) }\end{array}$ & $\begin{array}{c}\text { Change in } \\
\text { corporate tax } \\
\text { rate } \\
\text { (\%-points) }\end{array}$ & $\begin{array}{c}\text { Change in } \\
\text { capital } \\
\text { allowance rate } \\
\text { (\%) }\end{array}$ \\
\hline Austria & -0.1 & 0.0 & 0.0 & -2.5 & -10.4 \\
\hline Belgium & 1.9 & 0.4 & 0.0 & -2.5 & 28.2 \\
\hline Denmark & 0.0 & 0.0 & 0.0 & & \\
\hline Finland & 0.9 & 0.1 & -0.1 & 2.5 & 55.6 \\
\hline France & 1.5 & 0.2 & -0.2 & -3.5 & 21.9 \\
\hline Germany & -2.6 & -0.1 & 0.5 & -6.5 & -59.3 \\
\hline Greece & 0.0 & 0.1 & 0.1 & -3.5 & -13.4 \\
\hline Ireland & -1.6 & -0.3 & 0.9 & 19.0 & -3.6 \\
\hline Italy & 0.6 & 0.1 & -0.2 & -1.5 & 10.5 \\
\hline Luxembourg & 3.0 & 0.3 & -0.8 & 1.1 & 170.0 \\
\hline Netherlands & 1.8 & 0.3 & -0.3 & -3.0 & 36.5 \\
\hline Portugal & 0.4 & 0.0 & -0.1 & 4.0 & 37.7 \\
\hline Spain & -0.5 & 0.1 & 0.1 & -3.5 & -20.3 \\
\hline Sweden & 0.0 & 0.0 & 0.0 & & \\
\hline UK & 0.0 & 0.0 & 0.0 & & \\
\hline Cyprus & 0.0 & 0.0 & 0.0 & & \\
\hline Czech Rep. & 0.0 & 0.0 & 0.0 & & \\
\hline Estonia & 0.0 & 0.0 & 0.0 & & \\
\hline Hungary & 0.0 & 0.0 & 0.0 & & \\
\hline Latvia & 0.0 & 0.0 & 0.0 & & \\
\hline Lithuania & 0.0 & 0.0 & 0.0 & & \\
\hline Malta & 0.0 & 0.0 & 0.0 & & \\
\hline Poland & 0.0 & 0.0 & 0.0 & & \\
\hline Slovak Rep. & 0.0 & 0.0 & 0.0 & & \\
\hline Slovenia & 0.0 & 0.0 & 0.0 & & \\
\hline EU25 & -0.1 & 0.1 & 0.0 & & \\
\hline
\end{tabular}

Note: The harmonised corporate tax rate is $31.5 \%$.

Government budgets are balanced by adjusting income transfers.

Source: CETAX simulations. 
Table A.6. Enhanced Cooperation at weighted averages

\begin{tabular}{|c|c|c|c|c|c|}
\hline Member state & $\begin{array}{l}\text { Change in } \\
\text { GDP } \\
(\%)\end{array}$ & $\begin{array}{l}\text { Change in } \\
\text { welfare } \\
\text { (\% of GDP) }\end{array}$ & $\begin{array}{l}\text { Change in } \\
\text { total tax } \\
\text { revenue } \\
\text { (\% of GDP) }\end{array}$ & $\begin{array}{c}\text { Change in } \\
\text { corporate tax } \\
\text { rate } \\
\text { (\%-points) }\end{array}$ & $\begin{array}{c}\text { Change in } \\
\text { capital } \\
\text { allowance rate } \\
\text { (\%) }\end{array}$ \\
\hline Austria & 0.6 & 0.1 & -0.1 & 0.7 & 20.5 \\
\hline Belgium & 2.5 & 0.5 & -0.2 & 0.7 & 72.4 \\
\hline Denmark & 0.0 & 0.0 & 0.0 & & \\
\hline Finland & 1.4 & 0.1 & -0.2 & 5.7 & 109.3 \\
\hline France & 2.2 & 0.2 & -0.4 & -0.3 & 64.0 \\
\hline Germany & -1.9 & -0.1 & 0.4 & -3.3 & -45.3 \\
\hline Greece & 0.8 & 0.1 & -0.1 & -0.3 & 16.5 \\
\hline Ireland & -1.1 & -0.3 & 0.7 & 22.2 & 29.7 \\
\hline Italy & 1.4 & 0.1 & -0.3 & 1.7 & 48.6 \\
\hline Luxembourg & 3.7 & 0.5 & -0.6 & 4.3 & 263.2 \\
\hline Netherlands & 2.6 & 0.3 & -0.4 & 0.2 & 83.6 \\
\hline Portugal & 1.0 & 0.0 & -0.3 & 7.2 & 85.2 \\
\hline Spain & 0.3 & 0.0 & -0.1 & -0.3 & 7.1 \\
\hline Sweden & 0.0 & 0.0 & 0.0 & & \\
\hline UK & 0.0 & 0.0 & 0.0 & & \\
\hline Cyprus & 0.0 & 0.0 & 0.0 & & \\
\hline Czech Rep. & 0.0 & 0.0 & 0.0 & & \\
\hline Estonia & 0.0 & 0.0 & 0.0 & & \\
\hline Hungary & 0.0 & 0.0 & 0.0 & & \\
\hline Latvia & 0.0 & 0.0 & 0.0 & & \\
\hline Lithuania & 0.0 & 0.0 & 0.0 & & \\
\hline Malta & 0.0 & 0.0 & 0.0 & & \\
\hline Poland & 0.0 & 0.0 & 0.0 & & \\
\hline Slovak Rep. & 0.0 & 0.0 & 0.0 & & \\
\hline Slovenia & 0.0 & 0.0 & 0.0 & & \\
\hline EU25 & 0.4 & 0.1 & 0.0 & & \\
\hline
\end{tabular}

Note: The harmonised corporate tax rate is $34.7 \%$.

Government budgets are balanced by adjusting income transfers.

Source: CETAX simulations. 


\section{References}

Allers, M. A. (1994), Administrative and compliance costs of taxation and public transfers in the Netherlands, Groningen: Wolters-Noordhoff.

Bettendorf, L., J. Goerter and A. van der Horst (2006), "Who benefits from tax competition in the European Union?”, CPB Document, June 9, 2006 (CPB Netherlands Bureau for Economic Analysis).

Copenhagen Economics (2004), Economic effects of tax cooperation in an enlarged European Union. Study prepared for the European Commission. October 2004.

Danish Ministry of Taxation (2004), "Skatte- og afgiftssystemerne i de ti nye EU-lande”, Skat, April 2004. Available in Danish only.

Eggert, W. and P.B. Sørensen (2006), ”Does tax competition increase public sector inefficiency?", Working Paper, Economic Policy Research Unit, Department of Economics, University of Copenhagen, April 2006.

Erard, B. (1997), "The income tax compliance burden on Canadian big business", Carleton University, Department of Economics, Working Paper, 97-2.

European Commission (2001a), "Towards an Internal Market without tax obstacles: A strategy for providing companies with a consolidated corporate tax base for their EU-wide activities”, COM (2001) 582 final.

European Commission (2001b), "Company Taxation in the Internal Market”, Commission Staff Working Paper, SEC (2001) 1681.

European Commission (2003), “An Internal Market without company tax obstacles: achievements, ongoing initiatives and remaining challenges”, COM (2003) 726 final.

European Commission (2004), "European Tax Survey”, Commission Staff Working Paper, SEC (2004) 1128/2.

Eurostat (2003), Structures of the Taxation Systems in the European Union - Data 1995-2001, Office for Official Publications of the European Communities, Luxembourg.

Eurostat (2004), Structures of the Taxation Systems in the European Union - Data 1995-2002, Office for Official Publications of the European Communities, Luxembourg. 
KPMG (2004), “Corporate Tax Rate Survey”, KPMG International, January 2004.

Lanno, K. and M. Levin (2002), “An EU company without an EU tax? A corporate tax action plan for advancing the Lisbon process”, CEPS Research Report, April 2002.

Martinez-Serrano, A. and B. Patterson (2003), “Taxation in Europe: Recent Developments”, Working Paper, European Parliament, Directorate-General for Research, Economic Affairs Series ECON 131 EN, 01-2003.

Mendoza, E.G. and L.L. Tesar (1998), “The international ramifications of tax reforms: Supply-side economics in a global economy”, American Economic Review 88, 226-245.

Mendoza, E.G. and L.L. Tesar (2005), “Why hasn’t tax competition triggered a race to the bottom?”, Journal of Monetary Economics 52, 163-204.

Nicodème, G. (2006), “Corporate tax competition and coordination in the European Union: What do we know? Where do we stand?”, European Economy, Economic Papers No. 250, June 2006.

OECD (2003), “Revenue Statistics 1965-2002”, OECD Publications Service.

Pope, J., Fayle, R. and D. L. Chen (1990), “The compliance costs of public companies' income taxation in Australia 1986-87”, Australian Tax Research Foundation, Sydney.

Sandford, C. (1995), Tax compliance costs: measurement and policy, Bath: Fiscal Publications, cited in Productivity Commission (1997), Compliance costs of taxation in Australia, July 1996.

Slemrod, J. and M. Blumenthal (1993), “The income tax compliance cost of big business”, University of Michigan, Office of Tax Policy Research, Working Paper, 93-11, July.

Sørensen, P. B. (2000), “The case for international tax co-ordination reconsidered”, Economic Policy 31, 431-461.

Sørensen, P. B. (2001a), “Tax co-ordination in the European Union: What are the issues?”, Swedish Economic Policy Review 8, 143-196.

Sørensen, P. B. (2001b), "OECDTAX - A Model of Tax Policy in the OECD Economy", Technical Working Paper, Economic Policy Research Unit, University of Copenhagen, October 2001. 
Sørensen, P.B. (2002), "The German Business Tax Reform of 2000 - A General Equilibrium Analysis", German Economic Review, 3:347-378.

Sørensen, P. B. (2004a), “Company Tax Reform in the European Union”, International Tax and Public Finance, 11:91-115.

Sørensen, P. B. (2004b), "International Tax Competition: A New Framework for Analysis", Economic Analysis and Policy, 33(2): 179-192.

Sørensen, P.B. (2004c), “International tax coordination: regionalism versus globalism”, Journal of Public Economics 88, 1187-1214.

Wilson, J.D. (1999), “Theories of tax competition”, National Tax Journal 52, 269-304.

ZEW (2003), Company Taxation in the new EU Member States, Centre for European Economic Research (ZEW) and Ernst \& Young, Frankfurt am Main/Mannheim, November 2003.

Zodrow, G.R. (2003), “Tax competition and tax coordination in the European Union”, International Tax and Public Finance 10, 651-671. 


\section{CESifo Working Paper Series}

(for full list see www.cesifo-group.de)

1796 Louis Eeckhoudt, Béatrice Rey and Harris Schlesinger, A Good Sign for Multivariate Risk Taking, September 2006

1797 Dominique M. Gross and Nicolas Schmitt, Why do Low- and High-Skill Workers Migrate? Flow Evidence from France, September 2006

1798 Dan Bernhardt, Stefan Krasa and Mattias Polborn, Political Polarization and the Electoral Effects of Media Bias, September 2006

1799 Pierre Pestieau and Motohiro Sato, Estate Taxation with Both Accidental and Planned Bequests, September 2006

1800 Øystein Foros and Hans Jarle Kind, Do Slotting Allowances Harm Retail Competition?, September 2006

1801 Tobias Lindhe and Jan Södersten, The Equity Trap, the Cost of Capital and the Firm's Growth Path, September 2006

1802 Wolfgang Buchholz, Richard Cornes and Wolfgang Peters, Existence, Uniqueness and Some Comparative Statics for Ratio- and Lindahl Equilibria: New Wine in Old Bottles, September 2006

1803 Jan Schnellenbach, Lars P. Feld and Christoph Schaltegger, The Impact of Referendums on the Centralisation of Public Goods Provision: A Political Economy Approach, September 2006

1804 David-Jan Jansen and Jakob de Haan, Does ECB Communication Help in Predicting its Interest Rate Decisions?, September 2006

1805 Jerome L. Stein, United States Current Account Deficits: A Stochastic Optimal Control Analysis, September 2006

1806 Friedrich Schneider, Shadow Economies and Corruption all over the World: What do we really Know?, September 2006

1807 Joerg Lingens and Klaus Waelde, Pareto-Improving Unemployment Policies, September 2006

1808 Axel Dreher, Jan-Egbert Sturm and James Raymond Vreeland, Does Membership on the UN Security Council Influence IMF Decisions? Evidence from Panel Data, September 2006

1809 Prabir De, Regional Trade in Northeast Asia: Why do Trade Costs Matter?, September 2006 
1810 Antonis Adam and Thomas Moutos, A Politico-Economic Analysis of Minimum Wages and Wage Subsidies, September 2006

1811 Guglielmo Maria Caporale and Christoph Hanck, Cointegration Tests of PPP: Do they also Exhibit Erratic Behaviour?, September 2006

1812 Robert S. Chirinko and Hisham Foad, Noise vs. News in Equity Returns, September 2006

1813 Oliver Huelsewig, Eric Mayer and Timo Wollmershaeuser, Bank Behavior and the Cost Channel of Monetary Transmission, September 2006

1814 Michael S. Michael, Are Migration Policies that Induce Skilled (Unskilled) Migration Beneficial (Harmful) for the Host Country?, September 2006

1815 Eytan Sheshinski, Optimum Commodity Taxation in Pooling Equilibria, October 2006

1816 Gottfried Haber and Reinhard Neck, Sustainability of Austrian Public Debt: A Political Economy Perspective, October 2006

1817 Thiess Buettner, Michael Overesch, Ulrich Schreiber and Georg Wamser, The Impact of Thin-Capitalization Rules on Multinationals' Financing and Investment Decisions, October 2006

1818 Eric O’N. Fisher and Sharon L. May, Relativity in Trade Theory: Towards a Solution to the Mystery of Missing Trade, October 2006

1819 Junichi Minagawa and Thorsten Upmann, Labor Supply and the Demand for Child Care: An Intertemporal Approach, October 2006

1820 Jan K. Brueckner and Raquel Girvin, Airport Noise Regulation, Airline Service Quality, and Social Welfare, October 2006

1821 Sijbren Cnossen, Alcohol Taxation and Regulation in the European Union, October 2006

1822 Frederick van der Ploeg, Sustainable Social Spending in a Greying Economy with Stagnant Public Services: Baumol’s Cost Disease Revisited, October 2006

1823 Steven Brakman, Harry Garretsen and Charles van Marrewijk, Cross-Border Mergers \& Acquisitions: The Facts as a Guide for International Economics, October 2006

1824 J. Atsu Amegashie, A Psychological Game with Interdependent Preference Types, October 2006

1825 Kurt R. Brekke, Ingrid Koenigbauer and Odd Rune Straume, Reference Pricing of Pharmaceuticals, October 2006

1826 Sean Holly, M. Hashem Pesaran and Takashi Yamagata, A Spatio-Temporal Model of House Prices in the US, October 2006 
1827 Margarita Katsimi and Thomas Moutos, Inequality and the US Import Demand Function, October 2006

1828 Eytan Sheshinski, Longevity and Aggregate Savings, October 2006

1829 Momi Dahan and Udi Nisan, Low Take-up Rates: The Role of Information, October 2006

1830 Dieter Urban, Multilateral Investment Agreement in a Political Equilibrium, October 2006

1831 Jan Bouckaert and Hans Degryse, Opt In Versus Opt Out: A Free-Entry Analysis of Privacy Policies, October 2006

1832 Wolfram F. Richter, Taxing Human Capital Efficiently: The Double Dividend of Taxing Non-qualified Labour more Heavily than Qualified Labour, October 2006

1833 Alberto Chong and Mark Gradstein, Who's Afraid of Foreign Aid? The Donors' Perspective, October 2006

1834 Dirk Schindler, Optimal Income Taxation with a Risky Asset - The Triple Income Tax, October 2006

1835 Andy Snell and Jonathan P. Thomas, Labour Contracts, Equal Treatment and WageUnemployment Dynamics, October 2006

1836 Peter Backé and Cezary Wójcik, Catching-up and Credit Booms in Central and Eastern European EU Member States and Acceding Countries: An Interpretation within the New Neoclassical Synthesis Framework, October 2006

1837 Lars P. Feld, Justina A.V. Fischer and Gebhard Kirchgaessner, The Effect of Direct Democracy on Income Redistribution: Evidence for Switzerland, October 2006

1838 Michael Rauscher, Voluntary Emission Reductions, Social Rewards, and Environmental Policy, November 2006

1839 Vincent Vicard, Trade, Conflicts, and Political Integration: the Regional Interplays, November 2006

1840 Erkki Koskela and Mikko Puhakka, Stability and Dynamics in an Overlapping Generations Economy under Flexible Wage Negotiation and Capital Accumulation, November 2006

1841 Thiess Buettner, Michael Overesch, Ulrich Schreiber and Georg Wamser, Taxation and Capital Structure Choice - Evidence from a Panel of German Multinationals, November 2006

1842 Guglielmo Maria Caporale and Alexandros Kontonikas, The Euro and Inflation Uncertainty in the European Monetary Union, November 2006 
1843 Jan K. Brueckner and Ann G. Largey, Social Interaction and Urban Sprawl, November 2006

1844 Eytan Sheshinski, Differentiated Annuities in a Pooling Equilibrium, November 2006

1845 Marc Suhrcke and Dieter Urban, Are Cardiovascular Diseases Bad for Economic Growth?, November 2006

1846 Sam Bucovetsky and Andreas Haufler, Preferential Tax Regimes with Asymmetric Countries, November 2006

1847 Luca Anderlini, Leonardo Felli and Andrew Postlewaite, Should Courts always Enforce what Contracting Parties Write?, November 2006

1848 Katharina Sailer, Searching the eBay Marketplace, November 2006

1849 Paul De Grauwe and Pablo Rovira Kaltwasser, A Behavioral Finance Model of the Exchange Rate with Many Forecasting Rules, November 2006

1850 Doina Maria Radulescu and Michael Stimmelmayr, ACE vs. CBIT: Which is Better for Investment and Welfare?, November 2006

1851 Guglielmo Maria Caporale and Mario Cerrato, Black Market and Official Exchange Rates: Long-Run Equilibrium and Short-Run Dynamics, November 2006

1852 Luca Anderlini, Leonardo Felli and Andrew Postlewaite, Active Courts and Menu Contracts, November 2006

1853 Andreas Haufler, Alexander Klemm and Guttorm Schjelderup, Economic Integration and Redistributive Taxation: A Simple Model with Ambiguous Results, November 2006

1854 S. Brock Blomberg, Thomas DeLeire and Gregory D. Hess, The (After) Life-Cycle Theory of Religious Contributions, November 2006

1855 Albert Solé-Ollé and Pilar Sorribas-Navarro, The Effects of Partisan Alignment on the Allocation of Intergovernmental Transfers. Differences-in-Differences Estimates for Spain, November 2006

1856 Biswa N. Bhattacharyay, Understanding the Latest Wave and Future Shape of Regional Trade and Cooperation Agreements in Asia, November 2006

1857 Matz Dahlberg, Eva Mörk, Jørn Rattsø and Hanna Ågren, Using a Discontinuous Grant to Identify the Effect of Grants on Local Taxes and Spending, November 2006

1858 Ernesto Crivelli and Klaas Staal, Size and Soft Budget Constraints, November 2006

1859 Jens Brøchner, Jesper Jensen, Patrik Svensson and Peter Birch Sørensen, The Dilemmas of Tax Coordination in the Enlarged European Union, November 2006 